\title{
Pelatihan UKM Rumahan Industri Pangan sebagai Upaya Meminimalkan Kendala Berwirausaha
}

\author{
Ratih Kusumawardhani, Ignatius Soni Kurniawan*, Alfiatul Maulida, Agus Dwi Cahya \\ Program Studi Manajemen, Fakultas Ekonomi, Universitas Sarjanawiyata Tamansiswa, \\ Jln. Kusumanegara No. 121 Muja Muju, Umbulharjo, Yogyakarta, Daerah Istimewa Yogyakarta, Indonesia
}

Submisi: 01 Juni 2019 ; Revisi: 30 Januari 2020; Penerimaan: 05 Februari 2020

\author{
Kata Kunci: \\ Industri pangan \\ rumahan \\ Inovasi produk \\ pengemasan \\ Pengelolaan \\ modal usaha \\ Perizinan P-IRT
}

\begin{abstract}
Abstrak Tujuan utama program ini adalah memberikan pembekalan dan pelatihan mengenai perizinan P-IRT, inovasi produk, pengelolaan keuangan, dan pemasaran produk bagi pemilik industri rumah tangga. Pengabdian masyarakat dilaksanakan pada 11 dan 12 November 2017 di Balai Desa Tirtoadi, Kecamatan Mlati, Kabupaten Sleman. Pengabdian masyarakat berjalan lancar dengan jumlah peserta sebanyak 26 orang dari 30 undangan. Materi yang disampaikan relevan dengan kebutuhan peserta yang sebagian besar menghadapi masalah terkait perizinan P-IRT, inovasi produk, manajemen keuangan, dan pemasaran produk. Pada saat pelaksanaan kegiatan, seluruh peserta aktif dan antusias mengikuti pelatihan hingga akhir sesi. Para peserta berharap agar kegiatan pengabdian masyarakat dilaksanakan secara berkesinambungan. Kegiatan pengabdian masyarakat juga bekerja sama dengan pusat kesehatan masyarakat (Puskesmas Mlati II) yang memberikan materi perihal perizinan P-IRT. Hasil pelatihan menunjukkan bahwa peserta dengan jenis kelamin perempuan (ibuibu) lebih antusias dalam mengikuti pelatihan daripada laki-laki. Hal tersebut tercermin dari permintaan peserta agar dilakukan pelatihan secara berkala.
\end{abstract}

Reywords:
Homemade
food industry
P-IRT licence
Packaging
capital
management
Product
innovation

ISSN 2460-9447 (print), ISSN 2541-5883 (online)

${ }^{*}$ Corresponding author : Ignatius Soni Kurniawan

Program Studi Manajemen, Fakultas Ekonomi, Universitas Sarjanawiyata Tamansiswa (UST) Yogyakarta, Jln. Kusumanegara No. 121, Kelurahan Muja Muju, Kecamatan Umbulharjo, Kota Yogyakarta, DIY 55165

Email:soni_kurniawan@ustjogja.ac.id 


\section{PENDAHULUAN}

Peran serta pemerintah pusat hingga daerah dalam mendorong terciptanya Usaha Kecil Menengah (UKM) yang kreatif, inovatif, dan berkembang semakin besar. Hal itu sejalan dengan hasil studi yang dilakukan oleh Sjaifudian et al. (1995) yang menyatakan bahwa telah banyak pembinaan pemberdayaan UKM yang dilakukan sejak dahulu oleh lembaga pemerintah (Deperin, Depdikbud, Depnaker, Depsos, Depkeu, Bapenas, Depkop dan PPK, Pemda bersama Bappeda serta Dinas Tata Kota), lembaga swasta, lembaga perorangan, Lembaga Swadaya Masyarakat, lembaga penelitian di perguruan tinggi, serta asosiasi pengusaha kecil dengan berbagai peran dan program yang dilakukan.

Dewan Perwakilan Rakyat Daerah (DPRD) juga mengusulkan agar ekonomi kreatif, koperasi, dan UKM mendapat perlindungan hukum secara jelas melalui Penerbitan Peraturan Daerah (Perda) (Handito, 2017). Sejalan dengan hal tersebut, Pemerintah Desa Tirtoadi, Kecamatan Mlati, Kabupaten Sleman juga memberikan dukungan kepada kelompok atau paguyuban UKM.

Desa Tirtoadi memiliki kelompok pelaku usaha berjenis kelamin laki-laki dan perempuan yang dikelola secara baik oleh pemerintah desa setempat. Pelatihan dan penyuluhan pada pengabdian masyarakat ini hanya diberikan kepada pelaku usaha berjenis kelamin perempuan (ibu-ibu). Berdasarkan penelitian yang dilakukan oleh Peel (2004) diketahui bahwa pemilik usaha berjenis kelamin perempuan cenderung lebih sering mengikuti pelatihan daripada yang berjenis kelamin laki-laki. Kurang lebih terdapat dua puluh pelaku usaha (ibu-ibu) yang bergerak pada industri makanan di Desa Tirtoadi. Pelaku usaha industri rumahan di Desa Tirtoadi memiliki potensi dan keterampilan yang besar. Hal tersebut dapat dilihat dari hasil produk olahan makanan yang beraneka ragam dan bervariasi, seperti roti kering, roti basah, dan keripik dari hasil olahan singkong. Dengan kompetensi tersebut, pada tahun 2016 Desa Tirtoadi berhasil menjadi perwakilan Kecamatan Mlati dalam kegiatan Lomba Desa Unggulan Kabupaten Sleman di bidang tata boga.

Pencapaian para pelaku usaha industri rumahan di Desa Tirtoadi tidak lepas dari dukungan berbagai pihak. Bentuk dukungan terhadap keberlangsungan hidup kelompok UKM, antara lain melalui berbagai penyuluhan dan pelatihan yang dilakukan oleh Dinas Pendidikan dan Kebudayaan Sleman, Dinas Usaha Mikro Kecil dan Menengah dan Koperasi Sleman, dan Pusat Kesehatan Masyarakat (Puskesmas) Mlati. Meskipun program penyuluhan dan pelatihan telah banyak dilakukan, kendala atau permasalahan masih dirasakan oleh para pelaku usaha. Kuncoro (2000) mengatakan bahwa permasalahan ini disebabkan oleh sering tumpang-tindihnya pembinaan UKM yang dilakukan oleh berbagai instansi (pemerintah dan nonpemerintah) karena adanya perbedaan persepsi sehingga arah pembinaan menjadi tidak efektif dan tidak adanya indikator keberhasilan yang seragam. Kuncoro (2000) lebih lanjut menjelaskan bahwa belum adanya keseragaman indikator keberhasilan tersebut disebabkan masing-masing instansi berupaya mengejar target dan sasaran sesuai dengan kriteria yang telah ditetapkan sendiri-sendiri.

Untuk mengantisipasi permasalahan seperti yang disampaikan Kuncoro (2000) tersebut, tim pengabdian masyarakat melakukan survei dan wawancara terhadap Pemerintah Desa Tirtoadi dan wakil pelaku usaha untuk mengumpulkan informasi terkait kendala yang dihadapi oleh UKM rumahan industri pangan. Adapun kendala yang dihadapi sebagai berikut. Pertama, tingkat keberhasilan pengajuan perizinan Pangan Industri Rumah Tangga (P-IRT) masih rendah. Hal itu menjadi kendala yang dihadapi oleh sebagian besar pelaku usaha industri rumahan di Desa Tirtoadi. Karakteristik pendidikan (banyak pelaku usaha yang berlatar belakang pendidikan SD dan SMP sehingga pengetahuannya terbatas) dan ekonomi menjadi salah satu penyebabnya. Kedua, kendala inovasi produk. Pelaku usaha dinilai masih kurang menguasai teknologi, manajemen, informasi, dan pasar sehingga berpengaruh terhadap tingkat pengetahuan perihal keberagaman produk dan kompetensi kewirausahaan. Ketiga, kendala dalam proses pengemasan produk dan jangkauan pemasaran. Keempat, kendala dalam hal akses modal dan pendanaan. Kurangnya tenaga pendamping di lapangan menyebabkan banyak pelaku usaha yang belum tersentuh layanan konsultasi dan pendampingan pengelolaan keuangan yang baik.

Secara keseluruhan, kendala yang dihadapi oleh UKM Desa Tirtoadi sejalan dengan temuan Kuncoro (2000), yakni bahwa pokok permasalahan yang menghambat produktivitas UMKM berkaitan dengan kualitas sumber daya manusia, khususnya di bidang manajemen, organisasi, penguasaan teknologi dan pemasaran, serta kompetisi kewirausahaan yang masih rendah. Pada penelitian yang dilakukan Kuncoro (2000) lebih lanjut menjelaskan bahwa kendala utama yang dihadapi UKM di Indonesia secara khusus sebagai berikut. Pertama, peluang memperoleh dan memperbesar pangsa pasar masih lemah. Kedua, kelemahan dalam struktur permodalan dan keterbatasan untuk memperoleh sumber-sumber permodalan. Ketiga, kelemahan di bidang organisasi dan manajemen sumber daya manusia. Keempat, keterbatasan jaringan usaha kerja sama antarpengusaha kecil (sistem informasi pemasaran). Kelima, iklim usaha yang kurang kondusif karena persaingan yang saling mematikan. Keenam, pembinaan yang telah dilakukan masih kurang terpadu dan kurangnya kepercayaan serta kepedulian masyarakat 
terhadap usaha kecil. Hasil tersebut diperkuat dengan studi yang dilakukan oleh Jones (2005), bahwa pelatihan penjaminan kualitas dan inovasi produk menjadi fokus perhatian utama bagi UKM di Negara Australia. Lebih lanjut, Jones (2005) menjelaskan bahwa ketertarikan UKM di Australia untuk mengikuti kegiatan pelatihan penjaminan kualitas mutu produk dan inovasi produk sangat tinggi.

Sebagai bagian dari Tri Dharma Perguruan Tinggi, dosen memiliki tanggung jawab untuk melaksanakan kegiatan pengabdian kepada masyarakat. Oleh karena itu, tim dosen Prodi Manajemen, Fakultas Ekonomi, Universitas Sarjanawiyata Tamansiswa (UST) bekerja sama dengan Pemerintah Desa Tirtoadi menyelenggarakan program penyuluhan dan pelatihan bagi kelompok UKM di Desa Tirtoadi. Materi penyuluhan dan pelatihan disusun berdasarkan permasalahan yang ada sehingga transfer pengetahuan diharapkan dapat terwujud sebagai bekal bagi para pengusaha rumahan di Desa Tirtoadi untuk meminimalkan, bahkan mengatasi kendala-kendala yang dihadapi.

Berdasarkan analisis situasi pada UKM rumahan industri pangan Desa Tirtoadi, Kecamatan Mlati, Kabupaten Sleman diketahui bahwa permasalahan yang dihadapi berkaitan dengan pengajuan perizinan P-IRT, inovasi produk, pengemasan dan distribusi pemasaran, serta pengelolaan keuangan atau modal usaha. Terkait hal tersebut, tujuan utama pelaksanaan kegiatan pengabdian masyarakat pada UKM rumahan industri pangan di Desa Tirtoadi, Kecamatan Mlati, Kabupaten Sleman adalah untuk memberikan pengetahuan dan pengalaman praktis mengenai perizinan P-IRT, inovasi produk, pemasaran produk, serta pengelolaan keuangan atau modal usaha.

Pelaksanaan program pengabdian masyarakat ini diharapkan akan memunculkan dampak positif dari sisi ilmu pengetahuan dan ekonomi pada kelompok UKM rumahan industri pangan di Desa Tirtoadi, Kecamatan Mlati, Kabupaten Sleman. Dampak ilmu pengetahuan dan teknologi tersebut berupa meningkatnya pemahaman mengenai proses perizinan P-IRT, meningkatnya pemahaman tentang strategi inovasi produk, meningkatnya pemahaman tentang pembuatan kemasan produk yang inovatif, dan meningkatnya pemahaman tentang pengelolaan keuangan atau modal usaha. Adapun dampak ekonomi berupa meningkatnya daya saing usaha yang akan berdampak pada peningkatan penjualan dan kesejahteraan kelompok UKM rumahan industri pangan di Desa Tirtoadi, Mlati, Sleman. Secara akumulatif, hal itu akan berdampak pada peningkatan perekonomian Desa Tirtoadi, Mlati, Sleman.

\section{METODE}

Metode pelaksanaan kegiatan menggunakan Participatory Learning and Action (PLA). Metode yang digunakan dalam pemberdayaan masyarakat tersebut dikenal dengan istilah learning by doing atau belajar sambil bekerja. Pemilihan metode disesuaikan dengan kondisi para peserta. Metode PLA, antara lain terdiri atas proses belajar melalui ceramah, tukar pendapat, dan diskusi.

Pelaksanaan dalam proses perijinan Pangan Industri Rumah Tangga (PIRT) diawali dengan pemohon mengisi formulir pendaftaran dan melampirkan dokumen identitas (KTP, Pas foto,) dan dokumen usaha (surat keterangan domisili usaha produk pangan, denah lokasi dan bangunan, surat keterangan sehat sanitasi, sampel produk dan kemasan, data produk dan modal usaha, surat keterangan penanggungjawab, dan surat keterangan usaha) di Dinas Kesehatan Kabupaten Sleman. Secara rinci, langkah pengajuan PIRT di jelaskan dalam (Gambar 1).

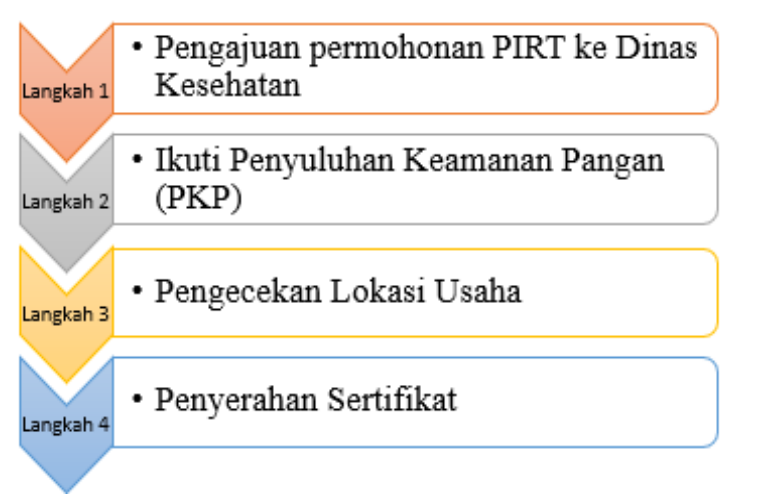

Gambar 1. Langkah pengajuan PIRT

Pengajuan PIRT, diawali dengan pengajuan permohonan PIRT ke Dinas Kesehatan, PKP, pengecekan lokasi usaha dan penyerahan sertifikat. Sementara, pelaksanaan pelatihan perizinan P-IRT dengan metode PLA yang ditekankan pada proses ceramah, tukar pendapat, diskusi, dan tanya jawab peserta. Proses kegiatan pelatihan perizinan P-IRT disampaikan secara langsung oleh pihak Puskesmas Mlati II dan Dosen Prodi Manajemen, Fakultas Ekonomi, UST.

\section{HASIL DAN PEMBAHASAN}

Program pengabdian masyarakat ini bertema "Perizinan P-IRT, Inovasi Produk, Pengemasan, Pemasaran Produk, serta Pengelolaan Modal Usaha sebagai Upaya Meminimalkan Kendala Berwirausaha pada UKM Rumahan Industri Pangan di Desa Tirtoadi, Kecamatan Mlati, Kabupaten Sleman”. Pemilihan tema berdasarkan hasil survei dan wawancara yang dilakukan tim dosen dari Prodi Manajemen, Fakultas Ekonomi, UST dengan Perangkat Desa Tirtoadi dan perwakilan pelaku usaha 
industri pangan tentang kendala-kendala yang dihadapi. Tema tersebut diharapkan tepat sasaran dan sesuai dengan yang dibutuhkan. Kegiatan penyuluhan dan pelatihan berlangsung selama dua hari, yaitu pada 11-12 November 2017 bertempat di Balai Desa Tirtoadi.

Penyuluhan dan pelatihan dilaksanakan selama dua hari agar hasil yang diperoleh efektif dan maksimal. Materi yang disampaikan pada hari pertama, Sabtu, 11 November 2017, terdiri atas materi perizinan P-IRT dan materi inovasi produk. Materi perizinan P-IRT disampaikan oleh dua narasumber, yaitu Ibu Ratih Kusumawardhani, S.E., M.Sc. (dosen dari Prodi Manajemen, Fakultas Ekonomi, UST) dan Ibu Dian Wahyu dari Puskesmas Mlati II. Perizinan P-IRT merupakan permasalahan utama yang dihadapi oleh sebagian besar pelaku usaha rumahan industri pangan di Desa Tirtoadi. Saat ini hanya satu pelaku usaha yang berhasil memperoleh izin P-IRT. Hal tersebut menunjukkan minimnya pelaku usaha yang mampu memperoleh perizinan P-IRT.

Kendala yang dihadapi terkait masalah perizinan $\mathrm{P}$ IRT adalah kurangnya pengetahuan tentang manfaat, kerugian, sanksi, cara memperoleh, dan tahapan proses pengajuan perizinan P-IRT. Oleh karena itu, materi perizinan P-IRT juga berhubungan dengan kendalakendala yang dihadapi. Pada saat penyuluhan dan pemaparan materi, peserta antusias dan bersemangat. Mereka mengajukan pertanyaan-pertanyaan kepada para narasumber dan mengungkapkan keluh kesah yang berkaitan dengan perizinan P-IRT.

Pada sesi kedua, setelah penyuluhan materi perizinan P-IRT, disampaikan materi inovasi produk. Selain kendala yang berkaitan dengan perizinan P-IRT, para pelaku usaha di Desa Tirtoadi juga mengalami kendala inovasi produk. Salah satu kendala inovasi produk yang dihadapi berkaitan dengan variasi hasil olahan makanan yang sedikit. Contohnya adalah hasil olahan dari singkong yang hanya dibuat menjadi keripik dan makanan tradisional (timus, cemplon, endog gludug). Di Desa Tirtoadi, sangat banyak ditemukan tanaman singkong, tetapi para pelaku usaha belum memanfaatkannya secara maksimal. Terkait hal itu, narasumber memberikan pengetahuan tentang langkahlangkah berinovasi, yaitu melalui informasi. Informasi dapat berasal dari berbagai sumber, salah satunya dari media elektronik (internet). Para peserta menyimak dengan cermat dan antusias saat bertanya serta menjawab pertanyaan. Sesi ini diharapkan dapat menambah wawasan peserta dalam menemukan inovasi produk makanan. Secara rinci, contoh hasil olahan singkong dengan adanya inovasi dan tidak disajikan dalam (Gambar 2)

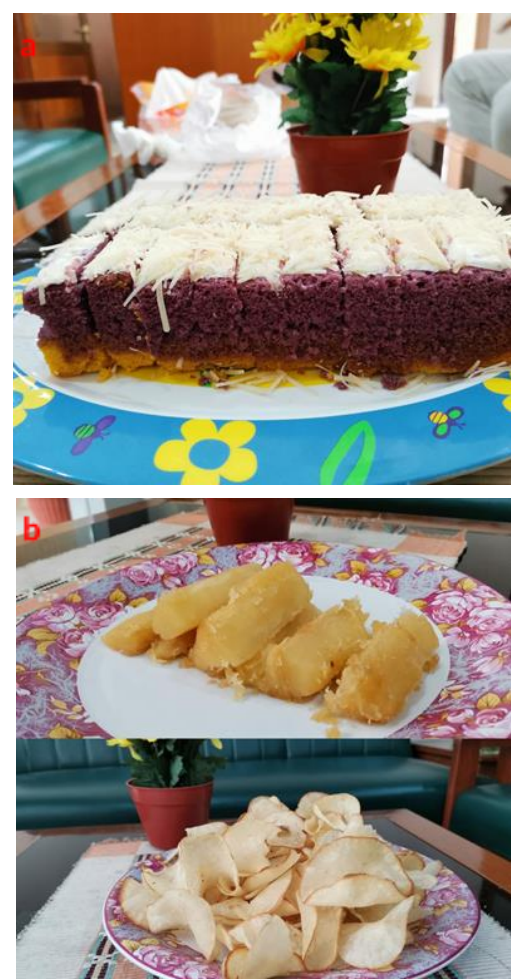

Gambar 2. Hasil olahan inovasi produk singkong (a) bolu kukus lapis; (b) singkong goreng

(Gambar 2) menyajikan hasil olahan makanan berbahan dasar singkong. (Gambar 2.a) menunjukkan hasil olahan singkong dengan adanya inovasi produk (dijadikan sebagai bolu kukus lapis). Sedangkan, (Gambar 2.b) menampilkan hasil olahan singkong yang tidak dilakukan inovasi (singkong goreng). Dapat dikatakan bahwa, inovasi produk mampu menambah nilai jual dari suatu produk.

Pelatihan pada hari kedua, Minggu, 12 November 2017, membahas materi pengemasan dan pemasaran produk serta pengelolaan keuangan. Materi pengemasan dan pemasaran produk disampaikan oleh Bapak Agus Dwi Cahya, S.Pd., M.M. Adapun materi pengelolaan keuangan disampaikan oleh Ibu Alfiatul Maulida, S.E., M.M. Kedua narasumber merupakan Dosen Prodi Manajemen, Fakultas Ekonomi, UST. Pengemasan dan pemasaran produk serta pengelolaan keuangan juga merupakan kendala-kendala yang dihadapi oleh UKM rumahan industri pangan di Desa Tirtoadi. Secara rinci, contoh kemasan produk disajikan dalam (Gambar 3).

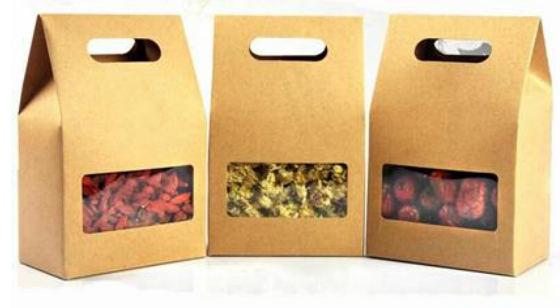

Gambar 3. Contoh pengemasan produk dengan bahan kertas. Sumber: wigatie (2017) 
Para pelaku usaha mengungkapkan permasalahan tentang terbatasnya jangkauan pemasaran hasil produksi mereka. Saat ini mereka hanya menjual hasil produksinya di lingkungan sekitar dan berdasarkan pesanan. Para pelaku usaha tersebut tidak memiliki akses pemasaran yang lebih luas. Peserta terlihat antusias saat narasumber menyampaikan materi, bahkan banyak pertanyaan yang disampaikan kepada narasumber pada sesi diskusi. Salah satu pertanyaan yang disampaikan terkait dengan kesulitan untuk menjual makanan ke Alfamart dan Indomart karena tidak adanya izin P-IRT. Dengan demikian, terdapat keterkaitan antara perizinan P-IRT dengan luasnya jangkauan pemasaran produk pangan.

Materi selanjutnya adalah pengelolaan keuangan sebagai modal usaha yang disampaikan oleh Ibu Alfiatul Maulida, M.M. Kendala pengelolaan keuangan yang dihadapi oleh para pelaku usaha di Desa Tirtoadi merupakan konflik yang terjadi dalam satu kelompok. Hal ini disebabkan sistem pengelolaan keuangan dilakukan secara berkelompok sehingga tergantung pada kelancaran pembayaran antaranggota. Permasalahan yang muncul adalah terdapat anggota kelompok yang mengalami gagal bayar sehingga mengganggu perputaran uang. Oleh karena itu, pemberian materi tentang pengelolaan keuangan kepada UKM rumahan industri pangan di Desa Tirtoadi adalah hal yang tepat. Para peserta mengikuti kegiatan dengan antusias dan menyimak dengan saksama. Narasumber juga memberikan informasi sumber-sumber pendanaan selain dari perbankan. Hal itu disebabkan sulitnya mendapatkan pinjaman dari perbankan juga menjadi kendala yang dialami para peserta. Salah satu alternatif yang disampaikan oleh narasumber adalah pinjaman melalui koperasi dan teman atau saudara.

Secara keseluruhan, hasil penyuluhan dan pelatihan yang dilakukan pada UKM rumahan industri pangan di Desa Tirtoadi menunjukkan bahwa peserta antusias dan bersemangat dalam mengikuti pelatihan pada setiap sesinya. Hal itu tampak ketika peserta menjawab pertanyaan dari narasumber dengan aktif dan menyampaikan pertanyaan dengan aktif pula, bahkan mereka mengungkapkan keluh kesah yang dialami selama ini. Pada sesi akhir kegiatan, perwakilan peserta juga memberikan masukan kepada narasumber agar pelatihan dapat dilaksanakan secara berkala karena mereka sangat membutuhkan pelatihan yang berkelanjutan.

Sejalan dengan hasil pelatihan yang dilakukan oleh Saugi \& Sumarno (2015), yang menunjukkan bahwa indikator keberhasilan pelatihan ditunjukkan dengan semakin meningkatnya pengetahuan dan ketrampilan peserta serta peningkatan pendapatan hasil. Hasil diperkuat dengan studi yang dilakukan oleh Primasari (2018); Sumarjono et al. (2009); Yudana \& Kusuma (2018), bahwa dampak positif pelatihan adalah proses produksi yang semakin efisien dan efektif serta dimiikinya wawasan yang luas tentang penggunaan teknologi khususnya dibidang pemasaran.

\section{KESIMPULAN}

Kesimpulan dari kegiatan yang telah dilaksanakan adalah para peserta masih membutuhkan banyak arahan dan wawasan tentang materi dan bimbingan yang berkaitan dengan perizinan P-IRT, inovasi produk, pengemasan dan pemasaran, serta pengelolaan modal usaha secara berkelanjutan. UKM, perlu mendapatkan saran, bimbingan dan pendampingan untuk mendapatkan perizinan P-IRT, inovasi produk, pengemasan dan pemasaran, serta pengelolaan modal usaha sesuai karakteristik usaha dan produk yang dihasilkan. Pembimbingan dapat dilakukan oleh pemerintah setempat atau pihak-pihak lain yang mempunyai kepentingan untuk mengembangkan UKM tersebut.

\section{DAFTAR PUSTAKA}

Handito. (2017). DPRD DIY Usulkan Ekonomi Kreatif, Koperasi, dan UKM Dilindungi Perda. Diakses dari https://jogja.tribunnews.com/2017/09/25/dprddiy-usulkan-ekonomi-kreatif-koperasi-dan-ukmdilindungi-perda.

Jones, J. (2005). The Determinants of Training in Australian Manufacturing SMEs. Education and Training, 47(8/9), 605-615. Diakses dari https://doi.org/10.1108/00400910510633143.

Kuncoro, M. (2000). Usaha Kecil di Indonesia: Profil, Masalah, dan Strategi Pemberdayaan. Sumber, 7 , 6-8.

Peel, D. (2004). Coaching and Mentoring in Small to Medium Sized Enterprises in the UK-Factors that Affect Success and a Possible Solution. International Journal of Evidence Based Coaching and Mentoring, 2(1), 1-11.

Primasari, I. (2018). Analisis Komunikasi Krisis Dicabutnya Sertifikasi Halal Toko Roti BreadTalk. Channel: Jurnal Komunikasi, 6(2), $191 . \quad$ Diakses dari https://doi.org/10.12928/channel.v6i2.11581.

Saugi, W. \& Sumarno. (2015). Pemberdayaan Perempuan Melalui Pelatihan Pengolahan Bahan Pangan Lokal. Jurnal Pendidikan Dan Pemberdayaan Masyarakat, 2(2), 226. Diakses dari https://doi.org/10.21831/jppm.v2i2.6361.

Sjaifudian, H., Haryadi, D., \& Maspiyati. (1995). Strategi dan Agenda Pengembangan Usaha Kecil. Bandung: Yayasan Akatiga.

Sumarjono, Subarkah, \& Suparnyo. (2009). Pelaksanaan Pelayanan Perizinan Usaha Perdagangan Secara Online oleh Dinas Penanaman Modal dan Pelayanan Terpadu Satu Pintu dalam Upaya Meningkatkan Investasi di Kabupaten Kudus. Jurnal Suara Keadilan, 19(1), 31-41. 
Wigatie, R. (2017). Pengemasan produk kerajinan bahan lunak. Retrieved March 4, 2020, from https://ragilwigatie.wordpress.com/2017/10/10/pe ngemasan-produk-kerajinan-bahan-lunak/ website: https://ragilwigatie.wordpress.com/

Yudana, I. G. P. H. \& Kusuma, I. G. N. A. (2018). Pembinaan Industri Rumah Tangga Kerupuk Ladrang Cepik Desa Tajen Penebel-Tabanan Bali. Widyabhakti Jurnal Ilmiah Populer, 1(1), 91-99. 